Ilmu Dakwah: Academic Journal for Homiletic Studies

Vol 10 No 2 Juli-Desember 2016 p-ISSN 1693-0843

Online sejak 21 Juni 2016 di http://journal.uinsgd.ac.id/index.php/idajhs DOI: http://dx.doi.org/10.15575/jid.v10i2.334

\title{
Akomodasi Komunikasi Mahasiswa Patani Thailand dalam Menghadapi Culture Shock
}

\author{
Safril $^{*}$ \\ STAIN Syaikh Abdurrahman Siddik Bangka Belitung \\ *savrilbangka@gmail.com
}

\begin{abstract}
This study aims to reveal the form of culture shock faced by students Patani Thailand as well as reveal the accommodation process communication convergence and divergence in which students Patani in UIN Sunan Gunung Jati Bandung. This type of research is qualitative and uses the method of Phenomenology. From these results obtained Patani students experience culture shock in the aspect of psychological and social aspects. Students Patani perform communication accommodation consist of pre, and post-process communication convergence and divergence accommodation is composed of verbal and non-verbal. The conclusion of this study is Patani Student 2015-2016 at the State Islamic University Sunan Gunung Jati Bandung experiencing Culture Shock, but they can be overcome by making accommodation communication convergence and divergence is quite effective so that they can survive (survive) and accepted by society in new environment that facilitate their purpose in Bandung is to study.
\end{abstract}

Keywords: Accommodation Communications, Student of Patani, Culture Shock

\section{ABSTRAK}

Penelitian ini bertujuan untuk mengungkap bentuk culture shock yang dihadapi oleh mahasiswa Patani Thailand serta mengungkap proses akomodasi komunikasi konvergensi (convergence) dan divergensi (divergence) yang dilakukan mahasiswa Patani di UIN Sunan Gunung Djati Bandung. Jenis penelitian ini kualitatif dan menggunakan metode Fenomenologi. Dari hasil penelitian ini diperoleh Mahasiswa Patani mengalami culture shock dalam aspek psikologis dan aspek sosial. Mahasiswa Patani melakukan akomodasi komunikasi terdiri dari tahap pra, proses dan pasca konvergensi dan akomodasi komunikasi divergensi yaitu terdiri dari verbal dan non verbal. Kesimpulan dari penelitian ini adalah Mahasiswa Patani Angkatan 2015-2016 di Universitas Islam Negeri Sunan Gunung Djati Bandung mengalami Culture Shock, namun bisa mereka atasi dengan melakukan akomodasi komunikasi secara konvergensi maupun divergensi yang cukup efektif sehingga mereka dapat bertahan hidup (survive) serta diterima masyarakat di lingkungan barunya sehingga memperlancar tujuan keberadaan mereka di Bandung yakni menuntut ilmu.

Kata Kunci: Akomodasi Komunikasi, Mahasiswa Patani, Culture Shock

Naskah diterima: 6 Sept 2016, direview 1 Nov 2016, disetujui: 14 Nov 2016 


\section{PENDAHULUAN}

Universitas yang menjadi pilihan terbanyak mahasiswa Patani untuk menuntut ilmu di Bandung adalah Universitas Islam Negeri Sunan Gunung Djati Bandung, itu dilatar belakangi basic Kampus UIN yang merupakan Kampus Islam serta pembiayaan yang lebih murah. Mahasiswa Patani yang berada di Bandung kemudian tergabung dalam Organisasi Persatuan Mahasiswa Islam Patani (Selatan Thailand) PMIPTI yang didirikan pada tanggal 25 September 1972. Lokasi sekretariat mereka ada di Bandung dan saat ini jumlah anggota aktif berjumlah 213 orang dari latar belakang kampus yang berbeda-beda. Pada angkatan 2015-2016 ini, PMIPTI telah merekrut 39 mahasiswa Patani baru yaitu 1 orang dari UNISBA, 6 orang dari UNINUS, 2 orang dari STKIP, 1 orang dari Kampus Al-Ghifari dan 20 orang dari UIN Sunan Gunung Djati Bandung. Motif utama mereka datang ke Indonesia sebagaimana dalam Buku Pegangan/Panduan PMIPTI Periode 2015-2016 adalah memang menuntut ilmu serta bermaksud mengembangkan misi kemahasiswaan dan misi perjuangan sebagai amanat penderitaan umat Islam Bangsa Melayu Patani untuk memperkenalkan dan menyampaikan kepada dunia internasional.

Perjuangan mahasiswa Patani untuk menuntut ilmu di Negara orang lain tidak mudah. Sebagai mahasiswa pendatang yang menuntut ilmu di daerah dengan latar budaya baru, mahasiswa Patani (Selatan Thailand) akan merasa asing ketika berada di UIN Sunan Gunung Djati Bandung karena memiliki latar budaya yang berbeda dari daerah asal mereka yang kemudian disebut sebagai culture shock. Mereka harus mampu menyesuaikan diri dengan lingkungan kampus UIN Bandung agar terhindar dari culture shock. Oberg (dalam Tri Dayakisni, 2008: 187) menggambarkan konsep culture shock sebagai respon yang mendalam dan negatif dari depresi, frustasi dan disorientasi yang dialami oleh orangorang yang hidup dalam suatu lingkungan budaya yang baru. Cara untuk mengatasi culture shock salah satunya dengan melakukan akomodasi komunikasi.

Proses adaptasi berupa akomodasi komunikasi antar budaya telah dirangkum oleh Howard Giles dalam sebuah teori komunikasi yakni Communication Accommodation Theory yang menyatakan bahwa dalam percakapan atau interaksi setiap orang memiliki pilihan. Mereka mungkin menciptakan komunitas percakapan yang melibatkan penggunaan bahasa 
atau system nonverbal yang sama (convergence), mereka mungkin akan membedakan diri mereka dari orang lain (divergence), atau mereka akan berusaha terlalu keras untuk beradaptasi (overaccomodation). (Girindra, 2012: 24)

Penelitian ini bermaksud mengungkap secara objektif pengalaman akomodasi komunikasi mahasiswa Patani (Selatan Thailand) angkatan 2015-2016 di UIN Sunan Gunung Djati Bandung dalam menghadapi culture shock yaitu mengetahui bentuk culture shock, proses akomodasi komunikasi konvergensi (convergence) dan proses akomodasi komunikasi divergensi (divergence) mahasiswa Patani (Selatan Thailand) di UIN Sunan Gunung Djati Bandung. Penelitian dilakukan melalui pendekatan kualitatif dan metode fenomenologi, yaitu berdasarkan redaksi murni hasil wawancara dengan mereka. Penelitian ini sangat penting sebagai penambah wawasan keilmuan tentang fenomenologi akomodasi komunikasi pendatang di suatu daerah atau kampus dalam menghadapi culture shock.

Salah satu penelitian yang berkaitan dengan penelitian ini yaitu penelitian Rahmat Paska Risalah dengan judul penelitian "Proses Adaptasi Speech Code Dalam Komunikasi Antarbudaya (Studi Deskriptif Kualitatif Mahasiswa Aceh yang Berinteraksi dalam Host Culture di Yogyakarta)". Penelitian tersebut bertujuan untuk mengungkapkan bagaimana Proses Adaptasi Speech Code Dalam Komunikasi Antarbudaya (Studi Deskriptif Kualitatif Mahasiswa Aceh yang Berinteraksi dalam Host Culture di Yogyakarta). Kedua penelitian ini sama-sama meneliti tentang adaptasi pendatang di suatu daerah. Rahmat Paska Risalah meneliti tentang Proses Adaptasi Speech Code Dalam Komunikasi Antarbudaya Mahasiswa Aceh dalam Host Culture di Yogyakarta, sedangkan penelitian yang akan dilalaksanakan ini meneliti tentang pengalaman komunikasi mahasiswa asal Patani (Selatan Thailand) di UIN Sunan Gunung Djati Bandung.

Penelitian ini bermaksud untuk mencoba menggali dan memaparkan tentang akomodasi komunikasi antar budaya yang dilakukan oleh mahasiswa Patani (Selatan Thailand) dalam menghadapi culture shock di Kampus UIN Bandung melalui metode fenomenologi dan berdasarkan teori akomodasi komunikasi.

Metode penelitian yang digunakan dalam penelitian ini adalah fenomenologi. Menurut salah satu tokoh fenomenologi, Edmund Husserl (dalam Engkus Kuswarno, 2009) menyatakan bahwa dengan fenomenologi kita dapat mempelajari bentuk-bentuk pengalaman dari 
sudut pandang orang yang mengalaminya secara langsung, seolah-olah kita mengalaminya sendiri. Metode fenomenologi ini merupakan pilihan metode yang sesuai karena merupakan penelitian yang dilakukan secara intensif terhadap suatu peristiwa atau fenomena yang digali melalui pengalaman individu yang mengalami peristiwa tersebut. Dalam konteks penelitian ini, peristiwa yang ditelitinya adalah proses akomodasi komunikasi antar budaya, sedangkan individu yang mengalaminya yang sekaligus menjadi subjek penelitian ini adalah Mahasiswa Patani (Selatan Thailand) di UIN Sunan Gunung Djati Bandung.

\section{HASIL PENELITIAN DAN PEMBAHASAN}

\section{Bentuk Culture Shock yang dialami Mahasiswa Patani.}

Berdasarkan hasil penelitian, beberapa bentuk culture shock yang dialami oleh Mahasiswa Patani saat datang ke Bandung Indonesia dapat dibagi menjadi dua aspek; pertama, Aspek Psikologis. Mahasiswa Patani sering mendengar suara serupa di malam hari yang membuat mereka ngeri dan takut. Suara itu sebenarnya adalah suara pagelaran seni musik gendang dan musik dalam acara pernikahan dan perayaan hari tertentu seperti perayaan HUT Kemerdekaan Indonesia. Mahasiswa yang belum tahu dan terbiasa bahkan kesulitan tidur dan sangat takut, itu disebabkan sugesti suara hantu masih tertanam dalam pikiran mereka. Setelah diberi pemahaman dan menyaksikan sendiri, suara yang dimaksud sebenarnya adalah suara pagelaran seni "gendang pencak silat" yang biasa dipentaskan terutama dalam perayaan kemerdekaan Indonesia. Meskipun telah mendapat penjelasan, masih saja beberapa mahasiswa Patani merasa takut saat mendengarnya di malam hari, terutama di komplek Cipadung Permai tempat kos-kosan mereka yang memang sepi di malam hari.

"Kalau budaya seperti di Bandung nih sangat beda ya, jadi apabila lihat tuh jadi merasakan banyak ya, seperti ada budaya yang mendengar suara membuat jadi ngeri.. takut. Dengan ting...ting...ting.... apa tuh, kalau disana tuh cuma kak dung dung...gitu. Disini, kalau dengar waktu malam sangat takut yah, sunyi yah. Sangat takut seperti ada acara kampong yang besarbesar tuh, kalo dengar gitu kalau waktu malam tuh sangat takut dengar begitu yah. Tapi yang tadi tuh yang dengar tuh, bahagia. Tari yang denga melodi dan suara yang tadi tuh takut." (Wawancara dengan Mr. Hafiz)

334 Ilmu Dakwah: Academic Journal for Homiletic Studies, Vol 10 No 2 | Juli-Des 2016 
Selain suara pagelaran musik dan tari, Mahasiswa Patani juga merasa tabu dan aneh dengan prosesi pernikahan di Bandung yang banyak perbedaan dengan tradisi pernikahan di Patani yang masih kental memegang syari’at Islam, sebagaimana petikan wawancara berikut:

"Apa sih itu dipanggilnya, ee... ade majelis perkawinan gitu. Kadang-kadang hamper same, ade harus dicuci kakinye...nah gitu, kadeng-kadeng disanepun masih ade, tapi nggak banyak dikit je. Banyak yang aneh. Apa sih tuh, banyekkan, jadi biase disane bagi perempuan gitu yang kawin tu nggak keluar disambut-sambutan tamu gitu. Disini ya pakainya biase same hamper same, gimana sih... Ya... ada tari, nari-nari ade nyanyinyanyi gitu, hehehe... lagu macem dangdut gitu...hehehe. Kalau di Patani pernikahan itu sakral, yaitu ya ngikut acara agama, tidak berlebihan tidak ada pesta nyanyi. Ada yang ngikut ajaran, kadadang nggak, tapi kebanyakan yang di Selatan adat Islam." (Wawancara dengan Miss Hartini).

Homesicknes rasa frustasi, tekanan pada lingkungan baru dan berbeda serta perasaan jauh dan kehilangan keluarga dan sahabat di tempat asal, membuat beberapa Mahasiswa Patani merasa tidak betah dan ingin pulang ke kampong halaman mereka. Meskipun ada yang berusaha mengatasi dengan berbagai cara, salah satunya yang disampaikan oleh Baruding, dalam wawancara ia mengaku sering ngobrol dan berkumpul bersama sesama mahasiswa Patani dan senior-seniornya disini dapat sedikit mengurangi rasa rindu ingin pulang kerumah. Sementara Marina mengatakan bahwa di Bandung ia merasakan banyak yang hilang. Yang hilang tersebut adalah karena awalnya ia terbiasa di rumah bersama orang tua begitu intens dan hanya di kampungnya saja, seperti petikan wawancara berikut:

"Kalau disini mah beda, nggak ada orang tua gitu, semuanya kita mengalami sendiri." (Wawancara dengan Miss Marina)

Rasa ingin pulang kerumah itu juga semakin memuncak saat Hari Raya Idul Fitri, seperti yang dirasakan oleh Husna dan Baruding juga, mereka sudah merasakan Idul Fitri di Bandung, dan rasanya sepi serta sedih. Gejolak rasa ingin pulang ke rumah sangat menggebu-gebu saat itu, seperti yang disampaikan dalam wawancara berikut:

"Iya. Hari raye tahun kemaren. Sepi, kangen same orang disane." (Wawancara dengan Miss Marina) 
Salah satu gejala bentuk culture shock ini terlihat dari tanggapan dan pernyataan para responden yang telah dipaparkan sebelumnya dalam penelitian ini yang saat ditanyakan tentang perbandingan antara budaya dan kondisi di Patani dan Indonesia cenderung memandang kebudayaan dan kondisi di Patani lebih baik. Pernyataan-pernyataan tersebut memang beralasan, tetapi tanpa disadari sebenarnya mereka sedang mengalami salah satu gejala culture shock. Seperti petikan wawancara berikut yang diungkapkan responden tentang perbandingan keberadaan pengemis di Indonesia dan Patani:

"Kalau orang Indonesia maaf ya, sering kalau sama cowok cewek itu nggak beda, sering gini-gini hehehe... kalau salam mah sentuhan juga, tapi kalau orang Patani mah nggak kalau salam begini... (tidak menyentuh)" (Wawancara dengan Miss Marina)

Bahasa Patani berdasarkan dari hasil wawancara dan pengamatan terdapat kesamaan dalam kata-kata yang digunakan, karena memang Patani menggunakan Bahasa Melayu namun tidak semirip antara Bahasa Melayu Malaysia dan Indonesia. Selain kata-kata, perbedaan terdengar misalnya pada logat yang terdengar menyeret dan manja, kecepatan tempo berbicara yang cepat, nada yang didominasi tinggi dan konsonan yang banyak diakhiri huruf vokal "o" dan "e". Miss. Marina, salah satu responden mengatakan perbedaan dari cara berbicara masyarakat Patani dan Indonesia khususnya Bandung terletak pada tempo dan volume serta nadanya, seperti petikan wawancaranya berikut:

"Kalau di Bandung mah suaranya kecil tapi cepat, kurang terdengar, kurang ngerti dan kurang jelas." (Wawancara dengan Miss Marina)

Setiap daerah maupun Negara mempunyai budaya dan bentuk kesenian tradisional yang berbeda. Budaya dan tradisi tersebut umumnya dilatar belakangi georafis maupun warisan temurun dari nenek moyang masing-masing. Di Bandung misalnya, terdapat berbagai bentuk tradisi, budaya dan kesenian tradisional yang telah ada sejak dahulu yang hingga kini masih dilestarikan. Bentuk tradisi, budaya dan kesenian tersebut kemudian menjadi khas atau identitas bagi daerahnya yang kemungkinan besar akan terasa asing dan tabu bagi masyarakat daerah maupun Negara lainnya. Suatu Negara atau daerah misalnya mempunyai prosesi pernikahan, tari tradisional, pakaian tradisonal atau musik tradisonal yang sangat khas dan unik dan mungkin berbeda dan sulit diterima oleh

336 Ilmu Dakwah: Academic Journal for Homiletic Studies, Vol 10 No 2 | Juli-Des 2016 
Negara dan daerah lainnya, oleh sebab itu culture shock akan terjadi bagi seseorang yang memasuki kebudayaan asing tersebut.

Dampak dari perbedayaan budaya dan tradisi membuat seseorang akan merasa tidak nyaman dan tidak betah berada dilingkungan barunya. Dalam berbagai kesempatan akan selalu ada pendapat yang membandingkan dan menganggap budayanya lebih baik daripada budaya ditempat baru. Pendapat tersebut kemudian menjadi penguat ketidakbetahan seseorang dilingkungan atau daerah baru. Perasaan ingin pulang atau homesicknes akan selalu menghinggapi setiap pendatang di tempat baru dan kebudayaan berbeda dengan berbagai alasan ketidaknyamanan dan perbedaan yang dirasakan dilingkungan barunya. Perasaan-perasaan tersebutlah yang kemudian menjadi tantangan yang harus ditanggulangi pendatang dilingkungan baru dengan budaya berbeda tersebut. Tujuan keberadaan mereka di tempat baru serta keinginan untuk survive atau bertahan hidup dan diterima masyarakat di lingkungan barunya harus menjadi prioritas. Kendala ketidaknyamanan harus dipahami sebagai bagian dari proses yang harus dilalui agar tujuan utama dapat digapai di Negara dan daerah barunya.

Rasa ketidaknyaman atas budaya dan kebiasaan berbeda di lingkungan baru juga dapat dikatakan sebagai sebuah frustasi, sebagaimana pendapat Mulyanra dan Rahmat bahwa bila seseorang memasuki suatu budaya asing, semua atau hampir semua petunjuk itu lenyap. Ia bagaikan ikan yang keluar dari air. Meskipun anda berpikiran luas dan beritikad baik, anda akan kehilangan pegangan. Lalu anda akan mengalami frustasi dan kecemasan. Biasanya orang-orang menghadapi frustasi dengan cara yang hampir sama. Pertama-tama mereka menolak lingkungan yang menyebabkan ketidak nyamanan. (Deddy Mulyana, Jalaludin Rahmat, 2001)

Aspek Sosial, mahasiswa Patani memandang budaya pergaulan melanggar syari'at. dalam pergaulan, masyarakat Patani menjaga batasan antara lakilaki dan perempuan yang bukan mahromnya. Sementara walaupun sungkan dan merasa tidak enak menyatakannya, responden mengatakan bahwa di Indonesia banyak tidak terjaga batasan laki-laki dan perempuan, salaman yang bersentuhan termasuk hal kecil yang mereka anggap sudah melanggar, sebagaimana petikan wawancara berikut:

"Kalau orang Indonesia maaf ya, sering kalau sama cowok cewek itu nggak beda, sering gini-gini hehehe... kalau salam mah sentuhan juga, tapi kalau orang Patani mah nggak kalau salam begini... (tidak menyentuh)" (Wawancara dengan Miss Marina) 
Beberapa responden juga pernah menjadi korban kriminalitas. Salah satu yang membuat shock adalah pencurian yang menimpa mereka dan terjadi di dalam Masjid yang merupakan tempat ibadah. Fatimah misalnya, seperti yang diceritakan dalam kutipan wawancara berikut:

"Itu pertama kali ada, apa namanya, ada yang pernah temen sendiri yang hari raya tahun kemarin, hari raya idul Fitri, sudah sholat barang yang ada kayak tas, hp ini ada didalam yang dibelakang, kan didalam masjid, nggak di apa.Terus keluar lihat HPnya hilang. Iya dalam masjid terus pagi raya. Iya, kan di alunalaun. Tiga bulan. Iya lebih tinggi, jadi nggak ada yang dibuka tasnya gitu dalam masjid nggak ada ya." (Wawancara dengan Miss Fatimah)

Segi pakaian, masyarakat Patani yang mayoritas muslim sangat menjaga kesopanan dan batasan aurat. Dalam kesehariannya, muslimah di Patani menggunakan pakaian tertutup yakni jilbab panjang (biasanya jilbab persegi dengan warna gelap dan polos), baju longgar dan rok panjang. Beberapa responden perempuan bahkan menyatakan bahwa banyak wanita muslim di Patani menggunakan cadar sebagai penutup wajah. Pakaian yang menjadi pakaian tradisional dan khas untuk perempuan di Patani adalah "Baju Kurung". "Baju Kurung" merupakan baju khas Melayu, sementara untuk laki-laki disebut "Telok Belango". Sedangkan, banyak perempuan di Bandung yang dilihat oleh responden yang memakai pakaian longgar, panjang dan tertutup bahkan yang memakai cadar, namun jumlah perempuan yang memakai pakaian ketat, terbuka, sexy bahkan mengumbar aurat sangat banyak pula. Tak sedikit pula perempuan yang mereka nilai sudah memakai jilbab namun pakaiannya masih ketat dan menonjolkan bagian-bagian yang tidak pantas dipamerkan, sebagaimana wawancara berikut:

"Kalau di Patani tuh pakaiannye same ditutup aurat, disananya baju kurung gitu nggak ada baju yang sexy-sexy itu nggak ada. Ya, kalau saye lihat tu sangat beda same yang di Patani." (Wawancara dengan Mr. Baruding)

Salah satu Mahasiswa Patani bahkan menyayangkan sebagian Pengemis tersebut sebenarnya masih terlihat segar dan kuat yang sebenarnya mampu melakukan pekerjaan lain selain mengemis adalah Marina. Sementara Hartini mengatakan: 
"Ya. Ade yang itu kesini pertama disini banyak pengemis gitu, terus sangat menjadi ape sih... kadang-kadang kanak-kanak udah pengemis, ya jadi sanget tak, memang disini rakyat kan banyak yang susoh, tapi kenapa sih pergi meminta, begitu. Ya... tetap pengemis. Ape sih disini, jadi harus dikurangi, harus dibantu mengapa sih harus banyek pengemis gini, jadi sangat kebiasaan jadi budaya kan gitu. Kadang-kadang mampu kerje tapi terus mengemis gitu. Kadang-kadang mimpinnye ibu yang tuo-tuo minta berujuk sakit." (Wawancara dengan Miss Hartini)

Mahasiswa Patani masih memandang kurangnya budaya tertib di jalan raya. Kemacetan sering membuat mahasiswa Patani pusing dan stres terutama saat naik angkot yang banyak di jejali barang pasokan makanan dan sayuran belanjaan Ibu Rumah Tangga yang bau, seperti yang diungkap dalam petikan wawancara berikut:

"Pertama kali di Bandung ya, sebelum apa ee... jadi cara-cara lihat suasana gitu ya gimana ya... jadi kan kalau jadi pertama kali tuh naik angkot ya, jadi lihat-lihat suasana itu haru-hara gitu. Jadi kalau di tempatan saya itu ada yang api merah, api kuning, api hijau itu... Ya, jadi kalau di Cibiru yang mau ke Cibiru itu nggak ada kan, jadi haru-hara gitu. Macet, ya jadi macet." (Wawancara dengan Miss Rosnida)

Aspek sosial culture shock; memandang budaya pergaulan laki-laki dan perempuan di Bandung banyak melanggar syari'at Islam, memandang budaya dan syari'at Islam belum sepenuhnya dipatuhi dengan banyaknya kasus kriminalitas bahkan di Masjid, memandang masih banyak wanita muslim yang belum melaksanakan syari'at dalam berpakaian, memandang budaya malas dan mengemis yang bukan syari'at Islam masih banyak di Bandung, dan memandang masih kurangnya kesadaran membudayakan ketertiban berlalu lintas di Bandung memang menjadi masalah yang dirasakan bagi Muslim yang ta'at dan masyarakat Bandung sendiri, seharusnya mayoritas muslim dapat menggiring masyarakatnya kepada kehidupan yang Islami.

Kebudayaan, agama, dan adat istiadat erat kaitannya dengan kehidupan manusia. Baik dalam keadaan sendiri maupun saat bersosialisi dengan orang lain. Ketiganya sangat erat hubungannya. Pelaksanaan agama bisa dipengaruhi oleh kebudayaan dan adat istiadat daerah setempat begitupun sebaliknya agama akan memperngaruhi kebudayaan seseorang. Seseorang yang dibesarkan di lingkungan maupun didikan yang Islami dan menjunjung nilai agama tentu akan mempengaruhi 
kebiasaan, tradisi dan karakternya. Dengan membiasakan diri kita mengenal agama, dan budaya sejak kecil, maka budaya dan sikap bersosialisasi dengan lingkungan sekitar akan ikut berpengaruh. Seseorang yang dibesarkan dengan lingkungan yang Islami niscaya akan membentuk pribadi, psikologi dan kebudayaan yang sholeh dan ia akan merasa shock serta berfikir berulang-ulang ketika ada kebudayaan, agama, dan adat istiadat baru yang muncul di sekitar atau lingkungannya yang tidak sesuai dengan kaidah ke-Islaman.

Furnham dan Bochner mengatakan bahwa culture shock adalah ketika seseorang tidak mengenal kebiasaan-kebiasaan sosial dari kultur baru atau jika ia mengenalnya maka ia tidak dapat atau tidak bersedia menampilkan perilaku yang sesuai dengan aturan-aturan itu. (Dayakisni, 2008: 187) Mahasiswa Patani mulai mengenal kebiasaan-kebiasaan dan kultur dari lingkungan baru mereka di Bandung yang mayoritas Muslim namun masih banyak kebiasaan yang belum sesuai syari'at Islam maka Mahasiswa Patani tidak dapat mengikutinya.

Bentuk-bentuk culture shock yang dialami oleh Mahasiswa Patani tersebut umumnya memang terjadi pada setiap individu yang baru menempati lingkungan dan budaya yang baru, seperti yang telah diteliti pula oleh Ana Kholifah (Ana Kholifah, 2009: 38) yang menyimpulkan beberapa tanda-tanda Culture Shock yang perlu diketahui diantaranya yaitu: (a) merasa sedih dan sendiri/terasingkan, (b) temperamen cepat berubah, merasa sering goyah dan tidak berdaya, (c) terkadang disertai masalah kesehatan, seperti demam, flu, diare, (d) sering merasa marah, kesal, dan tidak mau berinteraksi dengan masyarakat sekitar, (e) mengaitngaitkan dengan kebudayaan di negara asal dan bahkan menganggap negara asal lebih baik, (f) merasa kehilangan identitas/ciri-ciri pribadi, (g) berusaha keras menyerap dan memahami semua kebiasaan yang ada dinegara barunya, (h) menjadi kurang percaya diri, (i) membentuk suatu stereotip (pencitraan yang buruk) terhadap kebudayaan baru.

\section{Proses Akomodasi Komunikasi Konvergensi (Convergence).}

Ada tiga bentuk proses akomodasi komunikasi konvergensi Mahasiswa Patani yaitu; Pra Konvergensi, Proses Konvergensi Komunikasi, dan Pasca Konvergensi Komunikasi. Proses Pra Konvergensi, Menghafal materi bahan obrolan, trik tersebut dilakukan

340 Ilmu Dakwah: Academic Journal for Homiletic Studies, Vol 10 No 2 | Juli-Des 2016 
oleh Mahasiswa Patani untuk mengurangi masalah dalam proses komunikasi pertama dengan orang asing. Bahan obrolan tersebut yakni seputar perkenalan umumnya. Mereka menanyakan nama, asal dan seputar asal usul komunikan.

Bahasa Sunda, bagi mahasiswa Patani merupakan kendala terbesar dalam proses akomodasi komunikasi mereka, sebagaimana yang terungkap dalam petikan wawancara berikut:

"Disitu, iya saye merasa salah satunya sayenya kurang buhasa lagi, kurang sosial same orang Indonesia lagi, kelingkungannya saye kurang lagi. Lembut ya, tapi saye sangat pusing ya. Dia ngobrol bahasa Indonesia terus campur bahasa Sunda gitu, jadi saye pusing saya belum ngerti bahasa Sunda, jadi terus temen-temen juga sering ngobrol campur bahasa Indonesia bahasa Sunda." (Wawancara dengan Baruding)

Usaha besar yang ditempuh Mahasiswa Patani dalam proses akomodasi komunikasi adalah dengan mengikuti pelatihan yang disediakan oleh Departemen Kemahasiswaan Patani di Organisasi PMIPTI yang mereka sebut "Mapraba". Kegiatan tersebut dilaksanakan kurang lebih tiga bulan sebelum kegiatan perkuliahan di kampus aktif dan dimulai. Dalam pelatihan tersebut mereka mendapatkan materi diantaranya Bahasa, Keorganisasian, Manajemen, Sosial dan Sejarah, seperti penjelasan responden dalam wawancara berikut:

"...disini ada pelatihan gitu ya, pelatihan berbicara bahasa Indonesia. Dulu tu kan ada orang Indonesia ya, sekarang dia ini hijrah di Patani sekarang, tapi masa saya datang kesini dia itu udah jadi dosen, saye kan diajari bahasa Indonesia, bila ngomong dimane ini? Masa enam bulan.” (Wawancara dengan Idris)

Tidak hanya permasalahan Bahasa Sunda, Bahasa Ilmiah yang banyak mereka temukan dalam proses perkuliahanpun menjadi kendala tersendiri yang menghambat proses komunikasi termasuk dalam menerima materi dan ilmu dalam mata kuliah. Salah satu yang menemukan kesulitan itu adalah Marina. Marina yang sebenarnya seorang yang semangat belajar mengaku tidak pernah menemukan katakata ilmiah dan istilah-istilah asing tersebut di Patani sebelumnya sebagaimana yang diungkap dalam petikan wawancara berikut:

"Kalau saya suka ngomong sama teman-teman di kelas, kan kalau di Bahasa Indonesia itu kan ada bahasa ilmiah itu kan ada bahasa ilmiah gitu kan kita nggak bisa, sering nanya sama teman. 
Psikologi, fisik entah apa, kan kata-kata itu maha kalau dirumah itu nggak pernah, di Patani itu nggak ada." (Wawancara dengan Marina)

Melakukan sebuah konvergensi komunikasi membutuhkan waktu dan usaha yang cukup keras, terutama bagi orang yang sebelumnya belum mengetahui betul tentang gaya dan bahasa komunikasi daerah yang akan ia tempati. Seseorang yang berada di tempat dengan budaya dan bahasa berbeda akan merasa kesulitan dalam komunikasi untuk itu mereka perlu melakukan konvergensi komunikasi mereka. Konvergensi komunikasi dimulai dengan melakukan persiapan-persiapan untuk mempermudah proses konvergensi sehingga menghasilkan hasil komunikasi yang efektif. Pra konvergensi komunikasi dapat dilakukan dengan cara menghafal terlebih dahulu materi yang akan menjadi bahan obrolan, belajar menggunakan bahasa kedaerah keseharian atau tradisional serta bahasa ilmiah tempat baru tersebut dan terutama mengikuti kursus atau pelatihan Bahasa tempat baru tersebut.

Menghafal materi yang akan menjadi bahan obrolan dengan orang di lingkungan baru akan membuat proses komunikasi menjadi tidak kaku. Pendatang bisa menjadi inisiator pemulai dan pembuka percakapan dengan orang-orang berbeda budaya di lingkungan barunya. Bahan obrolan awal biasanya bersifat basa-basi dan berbentuk perkenalan antar satu dengan yang lain. Belajar menggunakan bahasa daerah keseharian atau tradisional serta bahasa ilmiah di tempat baru juga perlu. Dalam obrolan sehari-hari biasanya terdapat bahasa pergaulan tidak baku maupun tradisional yang biasa dipakai dalam satu lingkungan dan menunjukkan keakraban. Meskipun tidak digunakan, namun harus difahami oleh sang pendatang. Mempelajari kata-kata tersebut terlebih dahulu sebelum memulai proses komunikasi akan lebih baik, sehingga semakin saling memahami makna dalam bahasa antar satu dengan yang lain maka akan terjadi komunikasi yang efektif dan hubungan sosial yang lebih akrab.

Mengikuti kursus atau pelatihan Bahasa di tempat baru merupakan langkah cerdas dan efektif sebelum memulai proses konvergensi komunikasi dengan orang lain yang berbeda bahasa dan budaya sebelumnya. Kursus dan pelatihan bahasa lebih baik dilakukan dengan orang yang berpengalaman dalam proses konvergensi pada masa sebelumnya maupun kepada masyarakat asli Negara atau daerah rantauan

342 Ilmu Dakwah: Academic Journal for Homiletic Studies, Vol 10 No 2 | Juli-Des 2016 
tersebut. Orang yang telah mengalami terlebih dahulu proses konvergensi biasanya mempunyai tips dan saran yang efektif berdasarkan pengalamannya. Selain itu, belajar langsung dengan masyarakat asli di tempat yang baru juga sangat baik, sehingga lebih banyak kesempatan untuk mendengar dan menemukan kata-kata baru dari penduduk aslinya. Kursus bahasa ini bisa juga diselenggarakan oleh satu badan maupun organisasi yang dapat memfasilitasi lebih baik berdasarkan pengalaman mereka, sehingga persiapan utnuk melakukan proses konvergensi akan lebih baik dan komunikasi tercipta lebih efektif.

Usaha-usaha dalam proses konvergensi komunikasi yang dilakukan oleh Mahasiswa Patani adalah bentuk usaha menuju konvergensi yang positif, sebagaimana yang dikemukakan Richard West dan Lynn H. Turner, 2008 yang menyatakan bahwa konvergensi dapat terjadi secara positif adalah ketika komunikator bertindak dalam suatu gaya yang mirip dengan komunikannya. Keputusan mereka untuk merubah dan mengakomodasi cara berkomunikasi mereka adalah bentuk proses mencapai tujuan konvergensi positif tersebut, yakni membuat proses komunikasi berjalan efektif dalam artian pesan antara satu dengan lain dapat dipersepsi dan diterima dengan baik.

Salah satu usaha konvergensi komunikasi Mahasiswa Patani seperti saat berbicara dengan mahasiswa atau orang Indonesia, jika ada yang tidak dimengerti mereka meminta mengulangi atau menanyakan ulang maksud dan kata-kata yang diucapkan oleh lawan bicara orang Indonesia tersebut, seperti yang dijelaskan dalam petikan wawancara berikut:

"Sangat sulit ya. Awal-awal datang tuh sangat sulit, jadi udah seperti temen dalam kelas yah, udah ngomong tuh sekali lagi tu minta diulang lagi." (Wawancara dengan Hafiz)

Sebagian Mahasiswa Patani faham dengan bahasa Melayu Malaysia yang cenderung lebih mirip dengan Bahasa Indonesia, jadi mereka lebih menggunakan Bahasa Melayu Malaysia yang di dominasi akhiran "e" dalam setiap katanya agar lebih mudah dimengerti komunikan, seperti wawancara berikut:

"Iya masih, kan ada yang ngomong Bahasa Melayu sama teman dalam kelas kan ada yang bisa pakai Bahasa melayu sama saya, iya jadi dia bisa." (Wawancara dengan Fatimah)

Banyak bertanya tentang suatu kata atau bahasa yang belum dimengerti ketika melakukan sebuah konvergensi komunikasi akan 
membantu mengurangi kesalah fahaman dalam proses komunikasi serta memberikan pengalaman dan tambahan ilmu kosa kata yang baru yang dapat digunakan pada proses konvergensi komunikasi selanjutnya. Dua orang yang berbeda budaya dan bahasa akan saling memaklumi atas perbedaan bahasa keduanya dan akan kemungkinan bersedia melayani pengulangan atau pertanyaan kosa kata yang belum difahami satu dengan lainnya. Saat mempraktekkan konvergensi komunikasi langsung dengan orang berbeda budaya dan memperbaiki langsung berbagai kesalahan dalam penggunaan kata dan bahasa akan memberikan pengalaman yang mudah dimengerti dan cepat diingat sehingga saat menemukan kata atau masalah yang sama akan dapat diatasi atas pengalaman sebelumnya. Bertanyalah jika ada kata yang tidak difahami karena jika hanya diam maka komunikasi tidak akan berjalan efektif dan kemungkinan berbagai kesalah fahaman akan terjadi, semisal saat diam maka lawan bicara atau komunikan akan merasa bahwa apa yang telah disampaikannya telah dimengerti dan difahami.

Untuk melakukan proses konvergensi komunikasi, seseorang bisa menggunakan bahasa atau cara komunikasi yang mungkin mirip atau telah diketahui bersama oleh kedua orang yang berbeda budaya. Misalnya, dua orang yang berbeda Negara dapat menggunakan Bahasa Internasional semacam Bahasa Inggris yang telah difahami berbagai Negara dan menjadi bahasa pemersatu di dunia. Dalam ranah Asia dapat menggunakan bahasa Melayu yang menjadi bahasa rumpun dan khas di beberapa negaranya, agar usaha konvergensi dapat lebih ringan untuk dijalani. Di Indonesia Bahasa Melayu Malaysia sangat akrab dan terdapat banyak sekali kesamaan, apalagi dengan hadirnya kartun Upin-Ipin yang digemari masyarakat Indonesia semakin membuat Bahasa Melayu Malaysia akrab ditelinga masyarakat Indonesia. Bahasa Melayu tersebut juga dimengerti oleh Negara dengan basic RAS Melayu seperti Patani, maka orang Patani dapat terlebih dahulu menggunakan Bahasa Melayu Malaysia untuk memudahkan konvergensi komunikasi di Indonesia sehingga tercipta komunikasi yang efektif.

Proses konvergensi yang dilakukan oleh Mahasiswa Patani sejalan pula dengan esensi komunikasi konvergensi yang dinyatakan oleh Alo (2001) yaitu sebagai model interaktif yang mengutamakan perubahan, pertukaran, perbandingan pola-pola perilaku yang mewakili suatu masyarakat dan menghasilkan komunikasi berlangsung sepanjang waktu 
dengan penetapan fokus yaitu hubungan timbal balik. (Alo, 2001) Merubah cara berbicara (baik dalam segi kata, intonasi dan kecepatan), pertukaran kosa kata, perbandingan pola prilaku antara masyarakat Patani dan Indonesia mereka lakukan dengan fokus tujuan agar terjadinya hubungan timbal balik dengan lingkungan baru mereka di Indonesia.

Usaha konvergensi juga diaplikasikan Mahasiswa Patani di kelas. Dalam interaksi pertama sekali mereka banyak mengalami kesulitan sehingga obrolan yang terjadi tidak lancar dan cepat berakhir. Namun Mahasiswa Patani tidak putus asa, mereka mencatat, menayakan apa arti kata-kata yang mereka dengar dari teman-teman Indonesia kemudian mereka aplikasikan dalam percakapan sehari-hari di kelas. Berikut petikan wawancara responden tersebut:

"Ya, jadi ngomong sama temen-temen itu. Iya dicatat, ada kosma dalam kelas gitu ya, dia mau tukar gitu, diskusi bahasa gitu. Saya nih sampai bahasa Patani, bahasa Thailand gitu, tapi dia itu sampai bahasa Sunda, Bahasa Indonesia gitu ya. Jadi terus catatan gitu." (Wawancara dengan Miss Rosnida)

Selain bahasa verbal, mahasiswa Patani juga menemukan beberapa cara komunikasi non verbal yang baru mereka temukan dan kemudian ikut mereka gunakan dalam keseharaian pergaulan di UIN Bandung, seperti yang disampaikan dalam petikan wawancara berikut:

"Belum, paling yang tau gini aja .... (gerakan permisi pas lewat) Saye kire same, kadang-kadang ada yang itu apa hal biasanya yang mau melintas kedepan kan (tangannya kebawah sambil menunduk), kalau sana kebelakang (tangannya dilipat kebelakang sambil menunduk), kalau kedepan seorang yang tak santun. Iya, disana tuh harus kebelakang." (Wawancara dengan Miss Hartini)

Penyesuaian atau akomodasi konvergensi komunikasi sangat penting dilakukan oleh setiap pendatang untuk keberlangsungan hidup mereka di tempat baru terutama dalam berkomunikasi. Seorang pendatang perlu menyesuaikan diri dalam bahasa, komunikasi baik verbal dan non verbal serta budaya di tempat baru selama mereka bersedia melakukannya untuk kepentingan bertahan hidup di negeri orang. Seorang pendatang setelah mempelajari kata-kata dan bahasa di lingkungan barunya, ia pun perlu mengaplikasikan kata dan bahasa yang mereka pelajari tersebut kedalam diskusi sehari-hari dilingkungan barunya untuk mengasah kemampuan akomodasi komunikasi serta 
mempererat hubungan sosial dengan lingkungan barunya agar mereka dapat diterima dan hidup dalam kenyamanan.

Pengaplikasian akomodasi komunikasi dilakukan secara bertahap dan dikembangkan secara bertahap pula. Seorang pendatang yang melakukan akomodasi dengan baik akan terlihat pada aplikasi akomodasi komunikasi konvergensi mereka yang menunjukkan progress yang baik dan semakin lancar. Pelaksanaan akomodasi komunikasi yang dilakukan secara terus menerus akan berdampak pembiasaan dan akan menimbulkan kemahiran berbahasa baru yaitu berbahasa asing. Bagi Mahasiswa pendatang di negeri asing, akomodasi komunikasi ini akan menjadi nilai tambahan bagi mereka menambah khasanah keilmuan dari hasil praktek akomodasi komunikasi yang mereka lakukan untuk bertahan di tempat rantauannya.

Usaha dan proses konvergensi yang dilakukan Mahasiswa Patani sesuai dengan konvergensi yang dimaksudkan oleh Giles Nikolas Copuland dan Justine Coupland (1991) yang mendefinisikan konvergensi (convergence) sebagai "strategi dimana individu beradaptasi terhadap prilaku komunikatif satu sama lain", misalnya orang akan beradaptasi terhadap kecepatan bicara, jeda, senyuman, tatapan mata dan prilaku verbal dan non verbal lainnya. (Richard, et al, 2008: 222.)

Unsur-unsur dalam komunikasi tersebut telah mereka konvergensikan, walaupun tidak sepenuhnya sesuai dengan cara berkomunikasi orang Indonesia sebagaimana yang telah dipaparkan di atas. Berdasarkan pengungkapan dari informan yang memang sudah agak lama yaitu hampir satu tahun tinggal di Indonesia khususnya di Bandung, mereka terlihat sudah menguasai bahasa percakapan di Indonesia terutama dalam segi bahasa, sudah terdengar penggunaan bahasa-bahasa Sunda misalnya sisipan kata "teh, mah, unk dan apa sih".

Dari penggunaan kata-kata yang diungkapkan para informan tersebut adalah menunjukkan bentuk konvergensi. Proses dan usaha tersebut sejalan dengan pendapat Giles dan para koleganya yang telah menetapkan sebuah pengamatan umum bahwa para pelaku komunikasi seringkali saling meniru perilaku komunikannya. Mereka menyebutnya pemusatan (convergence) atau penyamaan. Penyamaan ini tentu dilakukan untuk mencapai komunikasi yang efektif ketika berkomunikasi dengan orang-orang di lingkungan tempat mereka merantau.

346 Ilmu Dakwah: Academic Journal for Homiletic Studies, Vol 10 No 2 | Juli-Des 2016 
Mahasiswa Patani memang terlihat berusaha untuk membuat penyamaan (convergensi) dari Bahasa yang mereka gunakan. Mahasiswa Patani berusaha untuk mengakomodasi komunikasi mereka kepada Bahasa Indonesia ketika berkomunikasi walaupun masih banyak keliru penggunaannya dan tidak sesuai dengan EYD. Penggunaan kata dalam kalimat yang masih keliru tersebut misalnya "mudah-mudahan mengucapkannya" yang harusnya "mudah-mudah mengucapkannya". Mudah-mudahan jika diartikan dalam Bahasa Indonesia adalah kata pengharapan.

Proses konvergensi yang dilakukan oleh Mahasiswa Patani adalah untuk menciptakan komunikasi yang efektif, sebagaimana yang dijelaskan oleh Richard West dan Lynn H. Turner bahwa komunikasi yang menyatakan bahwa konvergensi akan terlihat efektif ketika komunikasi terjadi dengan menarik (attractive), terprediksi, dan mudah dimengerti. (Littlejohn, et al, 2009: 153)

Usaha yang mereka lakukan untuk mencapai tujuan tersebut diaplikasikan mulai dari usaha-usaha kecil seperti menghafal materi yang akan menjadi bahan obrolan, penggunaan Bahasa Melayu Malaysia yang lebih mirip Bahasa Indonesia agar lebih mudah dimengerti komunikan, mencatat, membaca, bertanya, dan mengaplikasikan kata dan bahasa yang baru mereka kenal sampai pada usaha besar yang mereka tempuh dengan mengikuti pelatihan yang disediakan oleh Organisasi PMIPTI adalah sebuah usaha yang sesuai untuk membentuk komunikasi konvergensi yang efektif tadi, dan hasilnya adalah terciptanya komunikasi yang menarik (attractive), terprediksi, dan mudah dimengerti meskipun antar orang yang berbeda budaya.

\section{Proses Akomodasi Komunikasi Divergensi Mahasiswa Patani}

Salah satu strategi yang mirip dengan divergensi adalah penetapan, di mana seseorang tetap menjaga gaya aslinya, terlepas dari perilaku komunikasi lawan bicara mereka. (Gallois, 2016: 7). Beberapa kebiasaan asli yang masih dipertahankan di Indonesia dan menjadi ciri khas Mahasiswa Patani yaitu misalnya dalam budaya berpakaian, pergaulan dan bahasa serta cara berbicara yang kesemuanya adalah bagian dari komunikasi yaitu komunikasi baik verbal maupun non verbal. Bentuk akomodasi komunikasi divergensi yang dilakukan oleh Mahasiswa Patani dalam hasil penelitian ini dapat di kategorikan menjadi dua bentuk yaitu: 1) Komunikasi Divergensi Verbal. 
Dalam berkomunikasi di Bandung, Mahasiswa Patani menggunakan bahasa tradisional Patani kepada sesama mahasiswa Patani. Sementara untuk berkomunikasi dengan orang Indonesia mereka menggunakan bahasa Indonesia yang masih kental dan tercampur dengan bahasa Melayu Patani dan Malaysia. Para responden mengaku bahwa mereka sebenarnya tidak banyak merubah cara berbicara dan juga bahasa saat berada di Indonesia. Sebagian besar cara, logat dan kata-kata yang mereka gunakan adalah sebagaimana yang mereka gunakan ketika di Patani juga dan sikap tersebut merupakan bentuk divergensi mereka. Alasan mereka adalah karena bahasa dan kata-kata antara Patani dan Indonesia hampir sama sehingga mereka sebagian besar mendivergensikan komunikasi mereka saat di Indonesia, sebagaimana kutipan wawancaranya berikut:

"Iya masih, kan ada yang ngomong Bahasa Melayu sama teman dalam kelas kana da yang bisa pakai Bahasa melayu sama saya, iya jadi dia bisa." (Wawancara dengan Miss Fatimah)

Bentuk aplikasi komunikasi divergensi yang dilakukan Mahasiswa Patani yaitu salah satunya saat akan memulai berbicara dengan mahasiswa dan orang Indonesia di yang baru mereka jumpai, mereka biasanya memberi tahu lebih dulu bahwa mereka berasal dari Patani Thailand. Dengan begitu, komunikan (orang Indonesia) biasanya menghindari penggunaan Bahasa Sunda atau bahasa yang sulit dimengerti dalam Bahasa Indonesia., seperti petikan wawancara berikut:

"Iya kasih tahu, saya tuh dari Patani jadi lebih baik pakai Bahasa Indonesia. (Wawancara dengan Mr. Hafiz)

Beberapa responden mengaku mempunyai banyak teman sekelas yang sama-sama berasal dari Patani sehingga mereka terbiasa menggunakan Bahasa Patani di kelas, dan teman-teman mereka yang berasal dari Indonesia yang awalnya meminta untuk tidak bicara Bahasa Patani karena tidak mengerti dan takut tersinggung akhirnya terbiasa bahkan sedikit banyak mereka juga akhirnya mengikuti bahasa yang mereka gunakan. Seperti petikan wawancara berikut:

"mmmm... kan sama temen, jadi banyakan teman-teman Patani ya, jadi suka ngomong sama temen Patani itu, jadi sering-sering teman-teman Indonesia itu: Ih nggak usah Bahasa Patani gitu ya." (Wawancara dengan Miss Rosnida)

348 Ilmu Dakwah: Academic Journal for Homiletic Studies, Vol 10 No 2 | Juli-Des 2016 
Beberapa tindakan yang menunjukkan divergensi pada seseorang yang memasuki lingkungan budaya dan bahasa baru yaitu dengan masih mempertahankan bahasa asal mereka saat bertemu dengan sesama pendatang dari asal tempat yang sama meskipun mereka berada di tempat atau lingkungan asing dan banyak orang berbeda budaya dan bahasa di sekitar mereka. Dalam melakukan komunikasi dengan orang lain yang berbeda budaya, mereka juga sering mencampur adukkan bahasa mereka dengan bahasa komunikan mereka meski dilingkungan komunikan yang berbeda budaya dengan mereka. Selain itu, orang yang datang ke Negara dan tempat asing memperkenalkan identitas asli mereka kepada orang lain yang berbeda asal dan budaya sehingga mereka berharap akan dapat pemakluman jika mereka masih melakukan divergensi dalam proses akomodasi komunikasi mereka.

Gallois juga menambahkan bahwa komunikasi divergensi yaitu dimana seseorang tetap menjaga gaya aslinya, terlepas dari perilaku komunikasi lawan bicara mereka. (Gallois, 2016: 7). Mahasiswa Patani tidak perlu bersusah payah sepenuhnya mengkonvergensi bahasa mereka menjadi Bahasa Indonesia atau dengan kata lain melakukan penetapan terhadap sebagian cara dan gaya komunikasi asli mereka karena sebagian kata dalam Bahasa Patani dan Thailand yang mereka ucapkan telah dimengerti oleh komunikan mereka yang berasal dari Indonesia.

Pakaian adalah salah satu bentuk komunikasi non verbal, sebagaimana yang disampaikan Rosenfeld dan T. G Plax bahwa pakaian yang kita kenakan bisa menyampaikan berbagai fungsi. Sebagai bentuk komunikasi, pakaian dapat menyampaikan pesan artifaktual yang bersifat non verbal. (Rosenfeld, 1997: 24-31). Mulyana juga mengatakan bahwa komunikasi nonverbal secara sederhana adalah semua isyarat yang bukan kata-kata, pakaian adalah termasuk salah satunya.

(Deddy Mulyana, 2005: 308)

Mahasiswi Patani mempertahankan kultur budaya berpakaian sesuai syari'at Islam ketika berada di Bandung. Jilbab panjang, pakean longgar, panjang dan tertutup menjadi pakaian identik mahasiswi Patani. Bahkan banyak mahasiswa dan masyarakat di sekitar UIN Bandung mengidentikkan mahasiswi Patani dengan jilbab panjang hitam dan jubah mereka, sebagaimana penjelasan responden dalam petikan wawancara berikut:

"Yang dipakai disini pakaian. Pakaian tu seperti, baju ya seperti yang perempuan tu baju kurung tetap, jilbab syar'i gitu." (Wawancara dengan Mr. Baruding). 
Mahasiswi Patani di UIN Bandung juga sepakat untuk menggunakan baju tradisional mereka pada hari senin saat hari kuliah di kampus. Baju yang dimaksud adalah baju kurung yang juga syar'i dan khas Melayu, seperti yang dijelaskan oleh Marina salah satu Mahasiswa Patani dalam wawancara berikut:

"Pakai itu dipanggil dengan Baju Kurung, yang cewek. Ya, biasanya pakai dikit. Sepakat buat hari senin dipakai, tapi itu bukan semua. Yang laki-laki baju Teluk Belanga." (Wawancara dengan Mr. Hafiz)

Beberapa atribut atau simbol yang menunjukkan identitas Patani juga masih dipasang dan digunakan oleh mahasiswa Patani di Indonesia. Simbol tersebut juga merupakan bagian dari bentuk divergensi komunikasi dengan Indonesia.

Simbol dan atribut tersebut adalah gapura atau gerbang dipasang dan dibuat sesuai dengan seperti yang ada di Patani sebagi simbol mengkomunikasikan perbedaan dan identitas mereka. Gapura juga menjadi simbol Islam dan menjadi benda yang sering dibuat masyarakat Patani untuk merayakan hari-hari besar agama Islam. Beberapa jenis permaianan seperti layangan besar juga masih terpampang dipamerkan di ruang utama sekretariat PMIPTI, sebagaimana yang dijelaskan dalam petikan wawancara berikut:

"Seperti ini ..... (menunjuk ke Gapura), iya pintu gerbang, ya di hari raye ni kebanyakan bangun pintu gerbang. Kalau banyakan pintu gerbang ni banyakan hari besar Islam, hari raya, kalau bukan hari raye ni bukan.” (Wawancara dengan Mr. Idris)

Dalam pergaulan sehari-hari, mahasiswa Patani juga tetap mempertahankan budaya pergaulan mereka yang menjaga batasan dalam bergaul dan berkomunikasi antara laki-laki dan perempuan. Kebiasaan mereka di Patani yang sangat ta'at terhadap syari'at Islam yang diaplikasikan dalam jarak batas antara laki-laki dan perempuan yang tetap terjaga, seperti dalam petikan wawancaranya berikut:

"Kalau orang Indonesia maaf ya, sering kalau sama cowok cewek itu nggak beda, sering gini-gini hehehe... kalau salam mah sentuhan juga, tapi kalau orang Patani mah nggak kalau salam begini... (tidak menyentuh)". (Wawancara dengan Miss Marina)

350 Ilmu Dakwah: Academic Journal for Homiletic Studies, Vol 10 No 2 | Juli-Des 2016 
Akomodasi komunikasi divergensi Non Verbal; mempertahankan tradisi pakaian yang sesuai syari'at Islam, membuat kesepakatan untuk menggunakan baju khas Patani yang Melayu Islami pada hari Senin di Kampus, memasang simbol dan atribut identitas Mahasiswa Islam Patani, dan mempertahankan budaya pergaulan sesuai syari'at Islam antara laki-laki dan perempuan yang dilakukan oleh Mahasiswa Patani adalah bentuk dari pengaruh budaya Islam yang membesarkan dan membentuk karakter dan psikologis yang Islami bagi mereka sehingga mereka akan melakukan divergensi termasuk dalam bentuk non verbal di lingkungan baru mereka.

Richard, Giles menyebutkan Divergensi sangat berbeda dengan konvergensi dalam hal bahwa ini merupakan proses disosiasi. Alih-alih menunjukkan bagaimana dua pembicara mirip dalam hal kecepatan bicara, tindak-tanduk atau postur, divergensi adalah ketika tidak terdapat usaha untuk menunjukkan persamaan antara para pembicara. Dengan kata lain, dua orang berbicara dengan satu sama lain tanpa adanya kekhawatiran mengenai mengakomodasi satu sama lain. (Richard, et al, 2008: 226)

Keputusan untuk divergensi yang dipilih oleh Mahasiswa Patani terkadang juga berdampak pada kebekuan komunikasi dan putusnya komunikasi dengan lingkungan, namun dibalik itu mereka sedang memberi jeda beristirahat bagi diri mereka sendiri untuk menghindari culture shock yaitu stres akibat usaha berlebih dalam melakukan konvergensi komunikasi.

Divergensi tidak dapat disalah artikan sebagai satu cara tidak sepakat atau tidak memberikan respon pada lawan bicara, divergensi juga tidak sama dengan ketidak pedulian, namun mereka memutuskan untuk mendisosiasikan atau memilih untuk menjauhkan diri untuk tidak berkomunikasi dengan alasan yang bervariasi. (Richard, et al, 2008: 226)

Akomodasi komunikasi menjadi salah satu cara manusia untuk survive atau bertahan hidup di tempat baru yang berbeda budaya. Dengan cara pendekatan-pendekatan yang tepat maka akomodasi dengan lingkungan baru bisa cepat diatasi. Memperoleh informasi dengan cara berkomunikasi adalah salah satu cara untuk mengetahui karakter-karakter seseorang yang belum kita kenali, suasana yang belum kita kenali juga dan tentunya dapat menyesuaikan diri dengan suasana serta kondisi yang menurut kita asing. Sesuai kodratnya, manusia adalah makhluk sosial maka dari itu berkomunikasi menjadi hal yang sangat penting dalam setiap kegiatan yang dilakukan. Salah satunya bertujuan untuk bertahan dan diterima oleh lingkungan baru. 
Bagi pendatang seperti Mahasiswa yang menuntun ilmu ke Negara lain, mereka melakukan akomodasi agar ia bisa diterima di suatu lingkungan baru tersebut. Kadang, saat proses akomodasi tersebut, tidak jarang seseorang itu mengalami hambatan. Banyak faktor-faktor yang mempengaruhinya. Misalkan saja ada seseorang yang memiliki sifat pendiam dan pemalu, akan sulit untuk beradaptasi di lingkungan barunya karena mungkin dia tertutup dan sulit untuk memulai komunikasi sehingga proses adaptasinya terhambat, bisa juga karena berbagai culture shock yang ia alami.

Akomodasi komunikasi konvergensi menjadi pilihan baik bagi setiap pendatang dalam suatu tempat dan lingkungan baru demi terciptanya komunikasi yang efektif sehingga ia dapat diterima dalam lingkungan barunya dan dapat bertahan hidup disana. Konvergensi yang dilakukan haruslah sebuah konvergensi yang positif, menurut pendapat Richard West dan Lynn H. Turner bahwa konvergensi dapat terjadi secara positif ketika komunikator bertindak dalam suatu gaya yang mirip dengan komunikannya. (Richard, et al, 2008: 225)

Akomodasi komunikasi yang dilakukan mahasiswa Patani sudah cukup efektif sehingga tujuan mereka melakukan akomodasi tersebut mulai tercapai. Tujuan akomodasi komunikasi yang dilakukan Mahasiswa Patani adalah untuk survive atau bertahan hidup serta diterima masyarakat di lingkungan barunya. Kendala dan masalah ketidaknyamanan atau culture shock mereka pahami sebagai bagian dari proses yang harus dilalui. Untuk mengatasi masalah tersebut, Mahasiswa Patani berusaha keras melakukan akomodasi komunikasi dalam usaha penyesuaian diri agar mempermudah mereka bertahan, melanjutkan hidup dan terlebih untuk mempermudah menerima pelajaran dalam perkuliahan sebagaimana tujuan kedatangan mereka ke UIN Sunan Gunung Djati Bandung.

\section{PENUTUP}

Bentuk culture shock yang dialami oleh Mahasiswa Patani yaitu terdiri dari aspek psikologis dan aspek sosial. Proses akomodasi komunikasi konvergensi mahasiswa Patani terdiri dari tahap pra, proses dan pasca konvergensi. Sedangkan proses akomodasi komunikasi divergensi Mahasiswa Patani yaitu terdiri dari verbal dan non verbal. 
Mahasiswa Patani Angkatan 2015-2016 di Universitas Islam Negeri Sunan Gunung Djati Bandung mengalami Culture Shock, namun bisa mereka atasi dengan melakukan akomodasi komunikasi baik secara konvergensi maupun divergensi. Akomodasi komunikasi yang dilakukan mahasiswa Patani sudah cukup efektif sehingga tujuan mereka melakukan akomodasi tersebut mulai tercapai yaitu untuk survive atau bertahan hidup serta diterima masyarakat di lingkungan barunya sehingga memperlancar tujuan keberadaan mereka di Bandung yakni menuntut ilmu.

Akomodasi komunikasi Mahasiswa Patani di UIN Sunan Gunung Djati Bandung, ada tiga entitas yang disarankan dalam penelitian ini: Bagi Mahasiswa Patani di Indonesia khususnya dan mahasiswa perantau di negara manapun umumnya disarankan untuk melakukan akomodasi komunikasi konvergensi karena akan memberikan dampak positif bagi kelancaran menuntut ilmu di negara orang lain. Bagi mahasiswa dan civitas akademika UIN SGD Bandung maupun kampuskampus Indonesia untuk selalu meningkatkan kualitas pembelajaran di kampus, dan pendidikan Indonesia umumnya serta memberi pelayanan terbaik kepada mahasiswa Patani dan mahasiswa pendatang lainnya agar kualitas dunia pendidikan di Indonesia semakin diperhitungkan oleh Negara lain. Dalam penelitian ini hanya menyoroti akomodasi Mahasiswa Patani pada angkatan 2015-2016 di Universitas Islam Negeri Sunan Gunung Djati Bandung dalam menghadapi culture shock melalaui studi Fenomenologi, untuk itu masih terbuka ruang untuk melakukan penelitian lanjutan dari penelitian ini dengan metodologi, objek Mahasiswa Patani yang lebih luas dan dengan teori penelitian lainnya.

\section{DAFTAR PUSTAKA}

Adyapradana, Girindra. 2012. Akomodasi Komunikasi Pemain Game Online Dalam Menghadapi Stereotipe, Tesis Magister Sains Ilmu komunikasi. Jakarta: Universitas Indonesia.

Dayakisni, Tri. 2008. Psikologi Lintas Budaya. Malang: UMM Press.

Gallois, Cindy, Tania Ogay, dan Howard Giles. 2016. Communication Accommodation Theory: A Look Back And A Look Ahead, Jurnal. Santa Barbara: University of California.

Kholifah, Ana. 2009.Pengaruh Culture Shock Terhadap Hasil Belajar Mahasiswa PPKN Angkatan 2007 Fakultas Ilmu Pendidikan 
Universitas Negeri Malang. Malang: Universitas Negeri Malang.

Kuswarno, Engkus. 2009. Metodologi Penelitian Komunikasi, Fenomenologi, Konsepsi, Pedoman dan Contoh Penelitian. Bandung : Widya Padjadjaran.

LB, Rosenfeld. dan Plax, T.G, 1997. Clothing as Communication, Journal ofCommunication, 27.

Littlejohn, Stephen W. dan Karen A. Foss. 2009. Teori Komunikasi. Jakarta: Salemba Humanika.

Mulyana, Deddy. 2003. Ilmu Komunikasi Suatu Pengantar. Bandung: PT. Remaja Rosdakarya.

Wawancara dengan Mr. Baruding (Mahasiswi Patani), Bandung, 4 Mei 2016.

Wawancara dengan Miss Fatimah (Mahasiswi Patani), Bandung, 4 Mei 2016.

Wawancara dengan Mr. Hafiz (Mahasiswi Patani), Bandung, 4 Mei 2016.

Wawancara dengan Miss Hartini (Mahasiswi Patani), Bandung, 5 Mei 2016.

Wawancara dengan Mr. Idris (Mahasiswi Patani), Bandung, 9 Mei 2016.

Wawancara dengan Miss Marina (Mahasiswi Patani), Bandung, 4 Mei 2016.

Wawancara dengan Miss Rosnida (Mahasiswi Patani), Bandung, 5 Mei 2016.

West, Richard dan Lynn H. Turner. 2008. Pengantar Teori Komunikasi: Analisis dan Aplikasi. Jakarta: Penerbit Salemba Humanika. 